\title{
Preface to the Volume 4 Issue 4 of Indian Pacific Journal of Accounting and Finance
}

I am pleased to welcome you to Volume 4 Issue 4 of the Indian-Pacific Journal of Accounting and Finance (IPJAF).

In this Issue 4, all the presentations are international research emphasising corporate social responsibility, accounting, financial reporting, and taxation.

In the first paper captioned "Corporate Social Responsibility on Financial Performance: A Study of the Bangladeshi DSE Listed Private Commercial Banks", Fatima Saki of Jatiya Kabi Kazi Nazrul Islam University, Bangladesh, examines the impact of corporate social responsibility (CSR) on the financial performance (FP) of Private Commercial Banks (PCBs) in Bangladesh. Ten (10) PCBs are selected as samples for the study from the Dhaka Stock Exchange (DSE) listed companies. Statistical analysis tools such as regression, analysis of variance (ANOVA), and correlation are applied to collected data to examine CSR's impact on selected banks' financial performance. In the study, net profit after tax (NPAT), earnings per share (EPS), net asset value per share (NAVPS), return on assets (ROA), return on equity (ROE), and market value per share (MVPS) are considered as dependent variables and the independent variable, corporate social responsibility (CSR). The findings reveal that the EPS, NAVPS and MVPS of the selected banks are significantly influenced by CSR $56.4,62.0$, and 59.8 per cent, respectively. In contrast, CSR has an insignificant relationship with NPAT, ROA, and ROE. The study also indicates a high degree positive and statistically significant correlation between CSR and financial performance (EPS, NAVPS, and MVPS). CSR influences financial performance essentially, so considering social benefits, the banks should perform CSR activities emphasizing educational, environmental, and health issues.

In the second paper entitled "Financial Performance Measurement of a Commercial Bank: A Case of Bank of China Hongkong", Dr Jeyaraj Sonai Singaram of Sino-British College (Partnership Program with Staffordshire University, UK), Guangxi University for Nationalities, Guangxi Province, P. R. China and Dr Sumathi, M. of NMSS Vellaichamy Nadar College, Madurai District, Tamilnadu State, India focus on measuring the financial performance of Bank of China's profitability, solvency, and liquidity using secondary data for the period from 2008 to 2017 . Various techniques such as horizontal, vertical, and ratio analysis are employed to measure financial performance. Statistical tools such as mean, standard deviation, and co-efficiency of variation measure financial data to emphasize the comparative and relative importance of presentation. The study reveals that BOC's horizontal and vertical analysis indicates a variable growth rate of percentage and amount of Hongkong Dollar (HK\$) due to external and internal operating environmental factors. Ratio analysis reveals that the BOC was conducted in a rational and normal way except 2008, 2012, 2013, and 2015 due to the Lehman brothers' mini-bond issue, Global financial crisis, Backdrop of shrinking international trade, extreme movements in commodity prices 
(oil prices) and frequent swings in financial markets. Based on the findings, BOC formulates the policies to overcome the factors that would help the investors identify the banking sector's nature and assist in making their investment.

In the third paper titled "Taxpayers' Knowledge and Compliance: Evidence from Direct Assessment Tax in Lagos State", Ishola Joseph O., Bello Abass O., and Raheed Lateef O. of Lagos State Polytechnic Ikorodu Nigeria examine the relationship between Tax Knowledge and Tax Compliance among Taxpayers: Evidence from Direct Assessment in Lagos State. The study adopts the survey research design to elicit responses from selected taxpayers in the Ikeja Lagos State of Nigeria to explore what they perceived as the relationship between tax knowledge and tax compliance regarding tax payment and tax filing of returns. Primary data was collected through a designed questionnaire and was administered using the Kaiser-Meyer-Olkin test. Cronbach Alpha was also used in establishing the sampling adequacy and reliability of the research instrument. The survey results were collected from 200 respondents in three categories in Lagos State with 190 valid responses, including self-employed, taxpayers in public and private establishments in Ikeja from October to November 2020. The study adopted a judgmental sampling technique. The data extracted from the questionnaires were analyzed using a simple table as descriptive and Pearson Correlation at $1 \%$ Level of Significance as inferential statistics. The findings revealed that the general tax knowledge was significantly related to tax compliance in payment terms $(r=.993, p=0.000)$ and tax compliance in terms of filing of returns $(r=.986, p=0.000)$. thus, the study concluded that there is a positive relationship between tax knowledge and tax compliance.

The IPJAF presence anchors on the service and perseverance of its editorial board, the editorial team, and authors. I want to express your participation profoundly in submitting high-quality papers for review and publication in IPJAF. Despite the success so far recorded, I implore all our friends and associates to continue to partner with IPJAF through submitting quality research and policy papers within our scope for publication.

I assure our prospective authors, regardless of the acceptance of your manuscripts or not, to continue to enjoy the benefits of IPJAF by providing a review process, which offers high quality and helpful reviews tailored to assist authors in improving their manuscripts. Finally, I confess your support as you and I work hard to make IPJAF the most authoritative journal on accounting and finance for the community of academic, professional, industry, society and government.

Thank you most sincerely for your continued interest, support, and patronage to IPJAF, while looking forward to more beneficial relationships in 2021.

\author{
Oluwatoyin Muse Johnson Popoola, PhD \\ Editor-in-Chief \\ popoola@omjpalpha.com
}

